\title{
ヘマトポルフィリン誘導体による 実験的角膜新生血管の光化学治療 Photodynamic Therapy of Experimental Corneal Neovascularization Using Hematoporphyrin Derivatives
}

\author{
尾花 明, 郷渡 有子, 松本 宗明, 三木 徳彦 \\ 大阪市立大学医学部眼科学教室 \\ T545 大阪府大阪市阿倍野区旭町 $1-5-7$ \\ TEL $06-645-2176$ FAX 06-634-3873
}

Akira Obana, Yuko Gohto, Muneaki Matsumoto and Tokuhiko Miki Department of Ophtalmology. Osaka City University Medical School 1-5-7 Asahi-machi, Abeno-ku, Osaka-shi, Osaka-hu 545, Japan

\section{要 旨}

ポルフィマーナトリウムによる光化学治療が角膜新生血管の閉塞に有効かどうかを実験的に 検討した。白色家兔眼にペレット包埋法で角膜新生血管を作成後、ポルフィマーナトリウム 2 $\mathrm{mg} / \mathrm{kg}$ 体重を静注し，24，48，72時間後にアルゴン緑レーザー（514nm）を3種類の強度で 照射した。新生血管閉塞の有無老細隙灯顕微鏡亡螢光造影検査, 光学顕微鏡標本で観察した。 照射強度 $38.2 \mathrm{~J} / \mathrm{cm}$ 以上では新生血管は閉塞するものの，照射野内の虹彩等の新生血管周囲の 組織も強く障害された。今回検討した条件では $19.1 \mathrm{~J} / \mathrm{cm}$ の照射を静注後24〜72時間の間に行 うのが、周囲の正常組織障害を軽度に抑えて新生血管を閉塞できる治療条件であることが判明 した。光感受性物貿非投与下でレーザーを照射した対照実験では，新生血管閉塞や虹彩の障害 を認めなかったので，治療眼の血管閉塞が熱作用によるとは考えられない。本光感受性物質党 使用した光化学治療は眼科領域の新生血管閉塞の新しい方法として期待できる。

キーワード：光化学治療，角膜新生血管，ヘマトポルフィリン誘尊体，アルゴンレーザー, 家鬼眼

\begin{abstract}
The efficacy of photodynamic therapy using porphymer sodium for occlusion of corneal neovascularization has been evaluated experimentally. After the corneal neovascularization had been developed on albino rabbit eyes by a pellet mounting method, $2 \mathrm{mg} / \mathrm{kg}$ of porphymer sodium was administered intravenously. Argon green laser $(514 \mathrm{~nm})$ was irradiated to the cornea with three varieties of energy at $24,48,72$ and 96 hours after the administration, respectively. Slit-lamp examination, fluorescein angiography and light microscopic study were performed to observe whether the
\end{abstract}

(平成 7 年12月28日受理，平成 8 年 3 月 7 日揭載決定)

(Received December 28th 1995, Accepted March 7th 1996) 
corneal new veesls were closed or not. With the exposure energy more than $38.2 \mathrm{~J} / \mathrm{crf}$, new vessels were occluded but surrounding normal tissues in the irradiation area such as the iris were severly damaged. Irradiation with exposure energy of $19.1 \mathrm{~J} / \mathrm{cm}$ during 24 and 72 hours after the administration of porphymer sodium was estimated more suitable to the treatment, because new vessel clusure was obtained with a mild damage of the surrounding normal tissue. Since new vessels were not closed in control groups which received laser irradiation without photosensitizer administration, it was supposed that the closure was not induced by thermal effect. The results of the $p$ resent study suggested that photodynamic therapy using this photosensitizer was a $n$ ew useful therapeutic agent for occlusion of ocular neovascularization.

Key words : Photodynamic therapy, Corneal neovascularization. Hematoporphyrin derivatives, Argon laser, Rabbit eye

\section{I 緒 言}

ヘマトポルフィリン誘導体 (HPD)"在用いた光化学 治療は，Doughertyら”の研究に上り悪性腫瘍の新た な治療法として注目されるようになった。悪性腫瘍の退 縮効果は光化学作用で生じた活性酸素などのフリーラジ カルが腫曒細胞を直接破壊すると考えられていた。。か し, 光感受性物質の病巣局所への流入や酸素の供給に, 血管系が重要な役割を果たすことから腫憿血管への作用 が注目され始めいーら，血管内皮細胞の障害が証明され

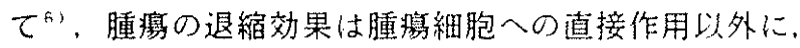
腫煌血管の閉塞による虚血の影響が考えられるように なった。光化学治療の血管への作用が研究されるにつ机， 眼科領域では新生血管治療への応用が考えられ，これま で動物実験で角膜新生血管》ー11，虹彩ルベオーシ

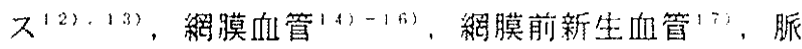

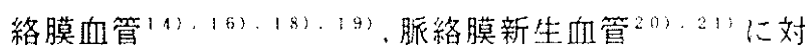
して，種々の光感受性物筫を用いた検討がなさ机てき た。

一方，我が国では1980年代から早田，加藤ら"2ー:4 によりHPDによる惡性腫瘦の治療が詳細に検討され。 本年HPDであるポルフィマーナトリウム(フォトフリ ン注、日本レダリー）が市肘され，肺癌、食道癌、罢癌、 子宮癌に対して臨床使用が可能となった。これにより格 ルフィマーナトリウムの人体投与の安全性が認めら放た わけで，今後，悪性腫演以外にも適灾搪大の可能性がひ らけた。そこで，我々は眼内に生じる新生血管治療にポ ルフィマーナトリウムを用いた光化学治療が有効かどう かを検討する目的で，奏験的角膜新生欰官を閉塞する研 究を行った。

\section{II 実験方法}

1.ペレット包埋法による角膜新生血管モデル作成方法 細潫灯および倒像鏡梌查で前眼部之眼底に異常の認め られない成熟白色家鬼28匹53眼在使用した。Ethylenevinyl acetate copolymer EVA 在徐放性基材として ウシ塩基性線維芽細胞增殖因子以下bFGF， R \& D systems) 500ngr含んだペレットを作成し"゙，塩酸 ケタミン(ケタラール 200mg/kg上キシラジン塩酸塩セ ラクタール $0.1 \mathrm{~m} \ell / \mathrm{kg}$ の筋注で全身麻酔徭，上方の角 膜輪部から約 $3 \mathrm{~mm}$ 離扎た陆膜実筫内にペレットを包埋し た。2 週間前後で角膜新生回管が輪部からペレットまて 達したものをモデルとして使用した。

\section{2. 光感受性物質}

ヘアトポルフィリン誘導体であるポルフィマーナトリ ウム(フォトフリン注) 在使用した。本品はPolyhem

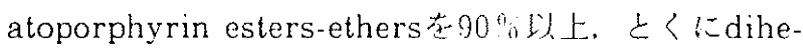
matoporphyrin ester-etherを約 $70 \%$ 念む。暗所で冷蔵 保存し，使用直前に5\%ブドゥ糖液にて溶解した。

\section{3. 光化学治療}

治療前の前眼部写真を撮影した。次に、正静脈からポ

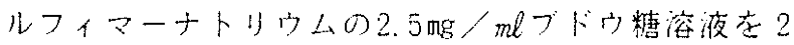
mg $/ \mathrm{kg}$ 体重の割台で注射し、静注後は暗所で飼青した。 静注徭24，48，72．96時間目に前記全身麻酔下にてアル コン緑レーザー(514nm) 芒照射した。照射は新生血 管の生じている角膜表面上垂直方向から，新生血管全体 が照射野の中央に位置拝るようにして，直径 $1 \mathrm{~cm}$ 範鬥 に行った。照射条件は弱度、中等度、強度の3種類之し た。すなわ方，弱度照射は角膜表面上の出力 $63.7 \mathrm{~mW}$ cmで5分間照射(総照射舅19.1 J $/ \mathrm{cm}$ )，中等度照射は 同出力で10分間照射（棇照射量 $38.2 \mathrm{~J} / \mathrm{cm}$ )。強度照射 
弱度照射

\begin{tabular}{|c|c|c|c|c|c|}
\hline & & \multicolumn{4}{|c|}{ レーザー照射から観察までの期間 } \\
\hline & & 3 時間 & $3 日$ & 1 週 & 2 週 \\
\hline \multirow{4}{*}{$\begin{array}{l}\text { ポルフィマーナトリウム } \\
\text { 静注からレーザ一照射ま } \\
\text { での時間（時間） }\end{array}$} & 24 & $3(1)$ & $2(1)$ & $1(0)$ & $1(1)$ \\
\hline & 48 & $2(1)$ & $1(0)$ & $1(0)$ & $1(1)$ \\
\hline & 72 & $2(0)$ & $2(1)$ & $1(0)$ & $1(1)$ \\
\hline & 96 & $1(0)$ & $1(0)$ & $1(1)$ & $0(0)$ \\
\hline
\end{tabular}

中等度照射

\begin{tabular}{|c|c|c|c|c|c|}
\hline & & \multicolumn{4}{|c|}{ レーザー照射から観察までの期間 } \\
\hline & & 3 時間 & 3 日 & 1 週 & 2 週 \\
\hline \multirow{4}{*}{$\begin{array}{l}\text { ポルフィマーナトリウム } \\
\text { からレーザー照射までの } \\
\text { 時間 (時間) }\end{array}$} & 24 & $5(1)$ & $4(1)$ & $2(1)$ & $1(1)$ \\
\hline & 48 & $4(1)$ & $3(1)$ & $2(1)$ & $1(1)$ \\
\hline & 72 & $4(1)$ & $3(1)$ & $2(1)$ & $1(1)$ \\
\hline & 96 & $4(1)$ & $3(1)$ & $2(1)$ & $1(1)$ \\
\hline
\end{tabular}

強度照射

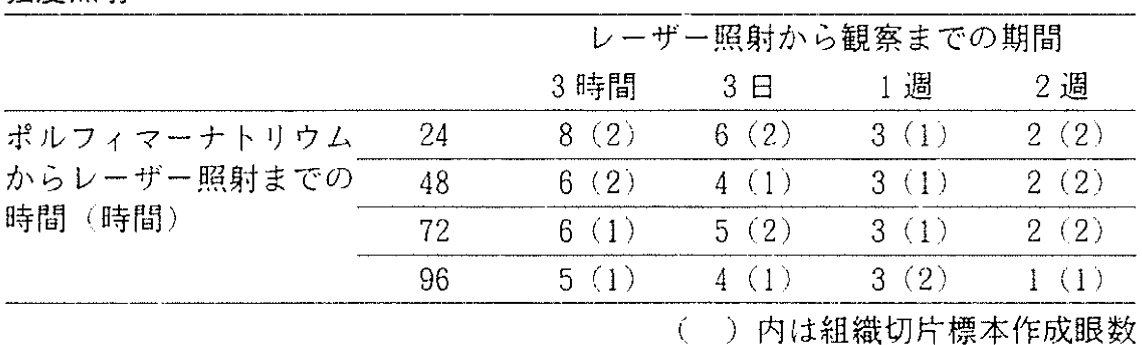

は出力 $127.4 \mathrm{~mW} / \mathrm{cm}^{2}$ で20分間照射(総照射量152.9 J厂 $\mathrm{cm}^{2}$ 〕であった。照射中は角膜の乾燥を防ぐため，適宜生 理食塭水を点眼した。

照射約 3 時間後， 3 日後，1週後，2週後に細䧋灯顕 微鏡, 倒像鏡で前眼部上眼底を観察し、前眼部抽よび眼 底写真撮影と前眼部螢光造影撮影を行った。また，各時 点で全身麻酔下で眼球摘出し，カルノフスキー液とオス ミウム酸による2重固定後, 型よ゙うりの処理でエポキシ 樹脂に包埋した。角膜と虹彩の組織切片標本を作成し， 光学顕微鏡（以下，光顕）で観察した。各照射条件上細

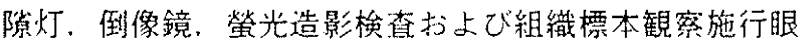
は表 1 のごとくとした。

\section{4. 対照実験}

ポルフィマーナトリウムを静注せずに、アルゴン緑 レーザーを2匹2眼に出力 $127.4 \mathrm{~mW} / \mathrm{cm}$ で20分間照射 し. 直後と翌日に細妳灯㧍上び螢光造影検查で新生血管 閵塞の有無在検討し，さらに，角膜上虹彩の組織切片標 本を光顕で観察した。きた１匹1眼はポルフィマーナ トリウムの静注のみを行い、レーザー照射䘮行和ずに他 上同样の条件で飼育し、静注直誖，1週後，2週㣪に細

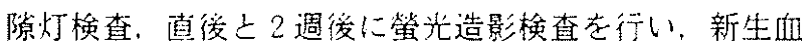

管閉塞の有無を観察した。

\section{III 結 果}

1. 細隍灯顕微鏡，倒像鏡，螢光造影所見

角膜新生血管の閉塞状況はポルフィマーナトリウム静 注からレーザー照射までの時間よりも，照射強度によっ てはば一定の傾向がみられたので，まず，各照射強度で の典型例の所見を記載する。

1) 弱度照射(ポルフィマーナトリウム静注24時間後 に照射した眼）

レーザー照射終了 3 時間後の細隌灯娭查で，新生血管 は助管径が太くなり，色調は照射前（図1）の赤色から 暗赤色に変化した（図 2 ）。レーザ一照射野内の角膜， 虹彩に著変はなく，瞳孔は正円であった。照射野の結膜 にわずかの浮腫を諗めた。螢光造影では新生血管の1本 は造影されたが、他は造影されず、照射野中央に位置す る虹彩に軽度の色秦漏出を諗めた〈図３）。3日後には 細陌灯検查で新生血䈏は不明隐で，ペレット周囲の角膜 に出血之軽度の混瀷が生じた。照射野内の虹彩に出血が みられた。結膜浮腫は軽減した（図 4)。螢光造影で新 生血管は造影さ机ず，照射野中央の虹彩に充盈欠損がみ 


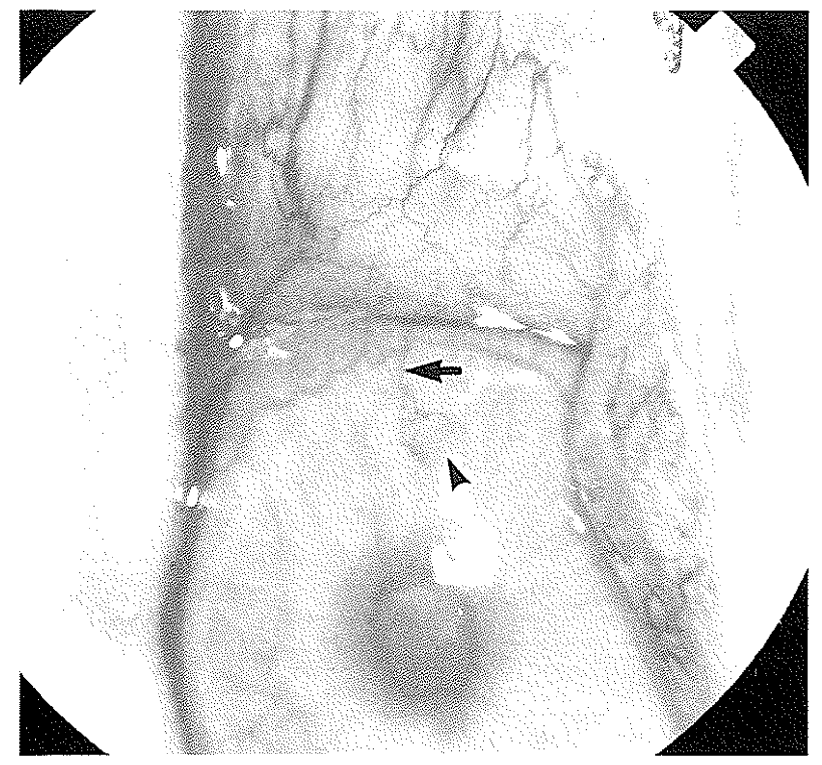

図1 ポルフィマーナトリウム静注24時間後の弱度照射 例。治療前前眼部写真。

角膜輪部からペレット(矢完)に達する解膜新生 血管（知印）がみら扎る。

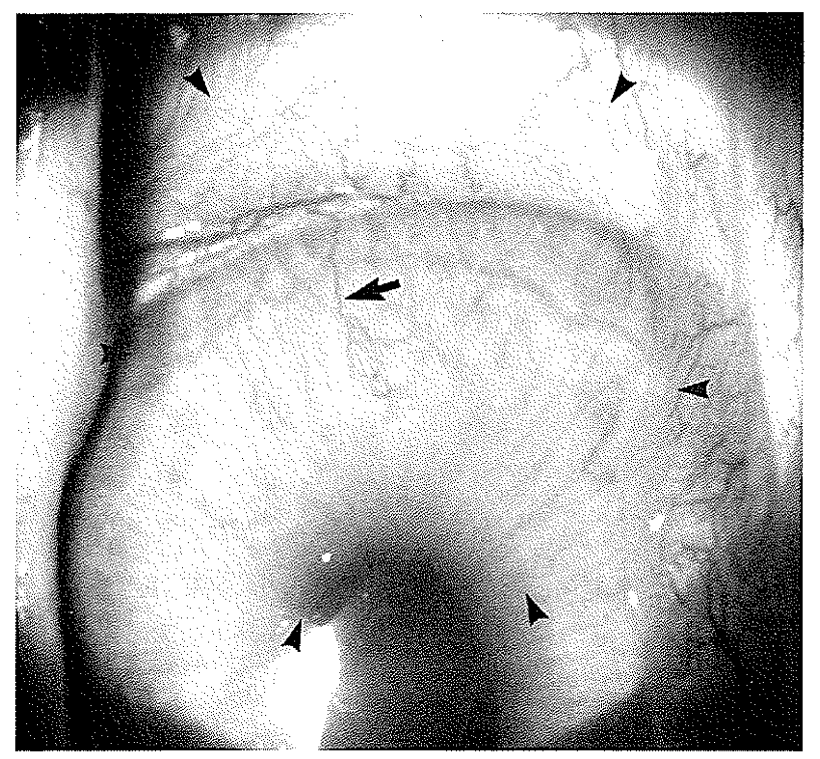

図 2 ポルフィマーナトリウム静注 24 時間後の弱度照射 例。治療 3 時間後の前眼部写真。

矢印で用まれた範井がはばレーザー照射部位であ る。矢印の新生血管は暗赤色を呈し，治療前より やや太い。結膜浮腫はごく軽度である。

られた（図 5)。1週徭には治療対象の新生血管は不明 であったが，治療時にはなかった新生血管が角膜輪郭に わずかに出現していた。角膜混濁は軽快し、虹彩には著 変を認めなかった。螢光造兒では元の新生血管は造影さ れなかった。照射野の虹彩の充盈欠損は3日㣪から明ら かに改善した。2 週後には元の新生血管は消失していた

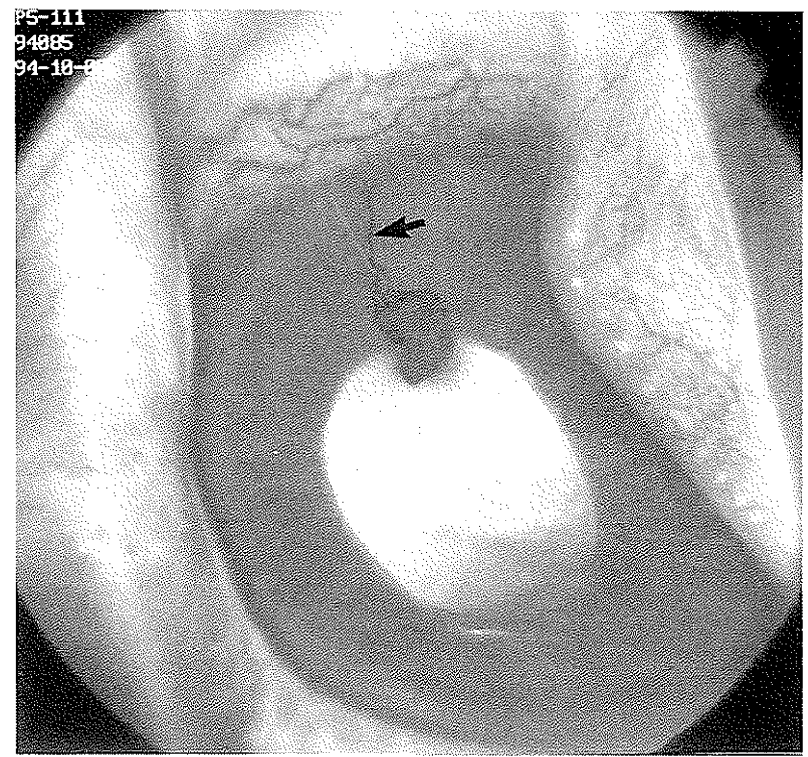

図 3 ポルフィマーナトリウム静注24時間㣪の弱度照射 例。治療 3 時間後の螢光造影写真。

(造影開始 1 分39秒)

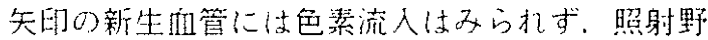
内の虹彩に軽度心過螢光が放执る。

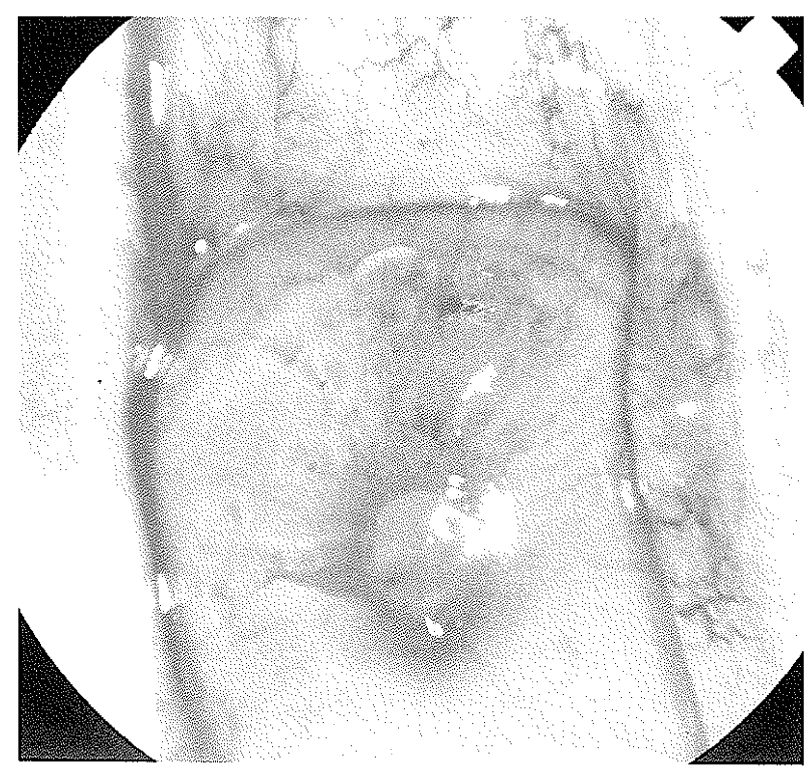

図 4 ポルフィマーナトリウム静注24時間後の弱度照射 例。治療 3 日後の前眼部写真。

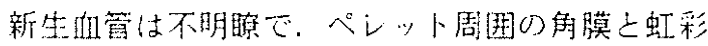
に出向かみられる。結膜浮腫は軽快している。

が、治痛後に出現した新生血管が1遇後上同程度にみら れた（図6)。照射部の虹彩に变化はみられなかった。 螢光造影では元の新生血管仕造影されなかった。照射野 の虹彩の立盈欠損は改善さ㣗た。なお，全経過在通じて

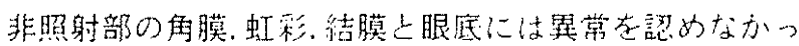
た。 


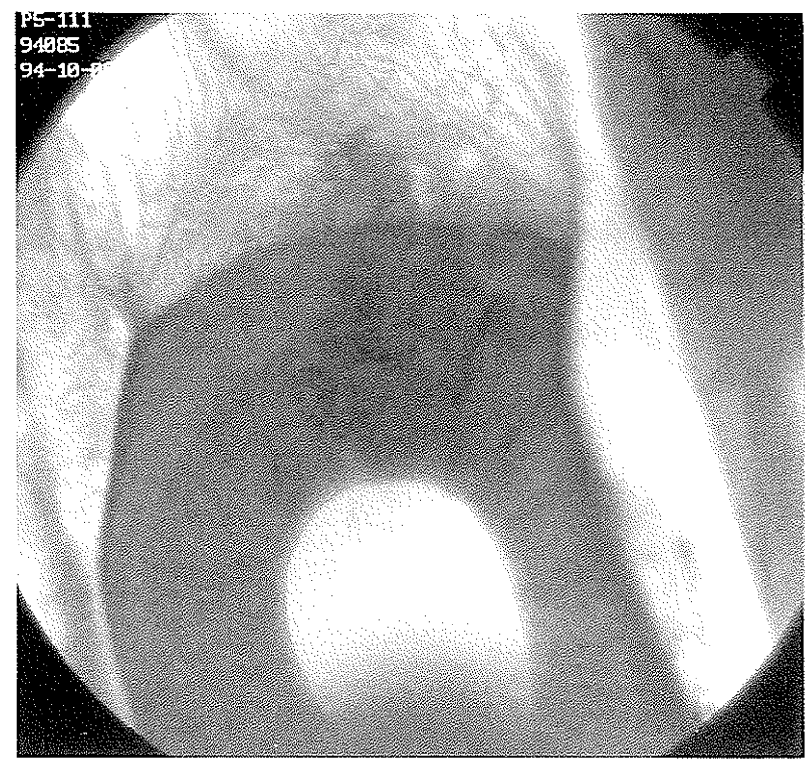

図 5 ポルフィマーナトリウム静注24時間後の弱度照射 例。治療 3 日後の螢光造影写真。

(造影開始 1 分39秒)

新生血管は造影されず，照射野中央の虹彩之輪部 近くの結膜は低螢光を呈する。

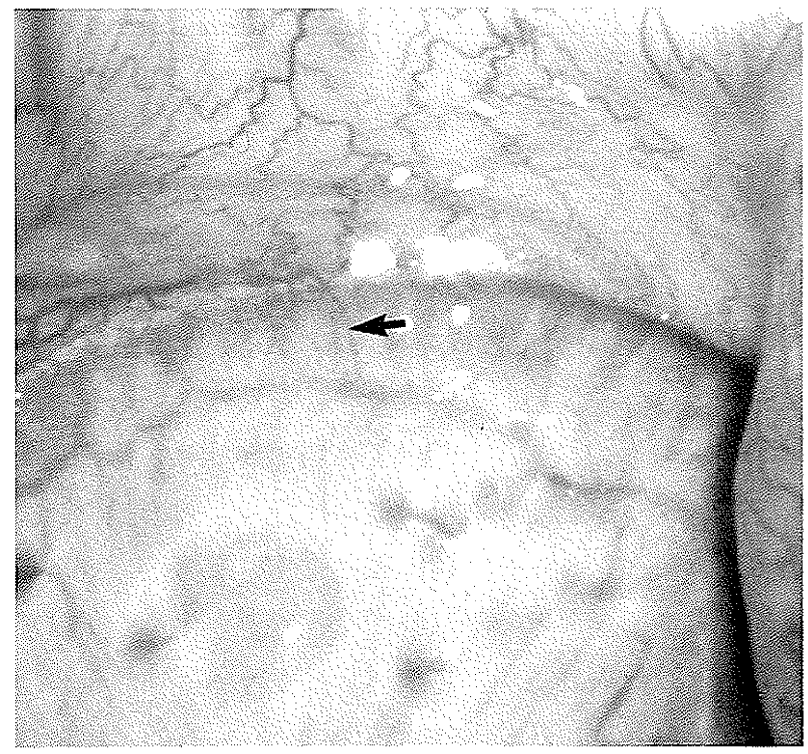

図 6 ポルフィマーナトリウム静注 24 時間後の弱度照射 例。治療 2 週後の前眼部写真。

元の新生血管は消失し，治療後出現した新生血简 (知印)は1週後と同程度である。

2) 中等度照射(ポルフィマーナトリウム静注72時間 㣪に照射した眼)

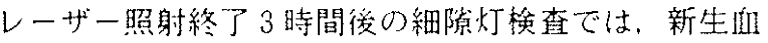
管は血管径が太く暗赤色になり，血流がみら㧈なか一た。 角膜混濁は生じなかった。レーザー照射野の虹彩は白色 謂で睡孔縁の虹彩向管が暗赤色となった。瞳孔ははば正

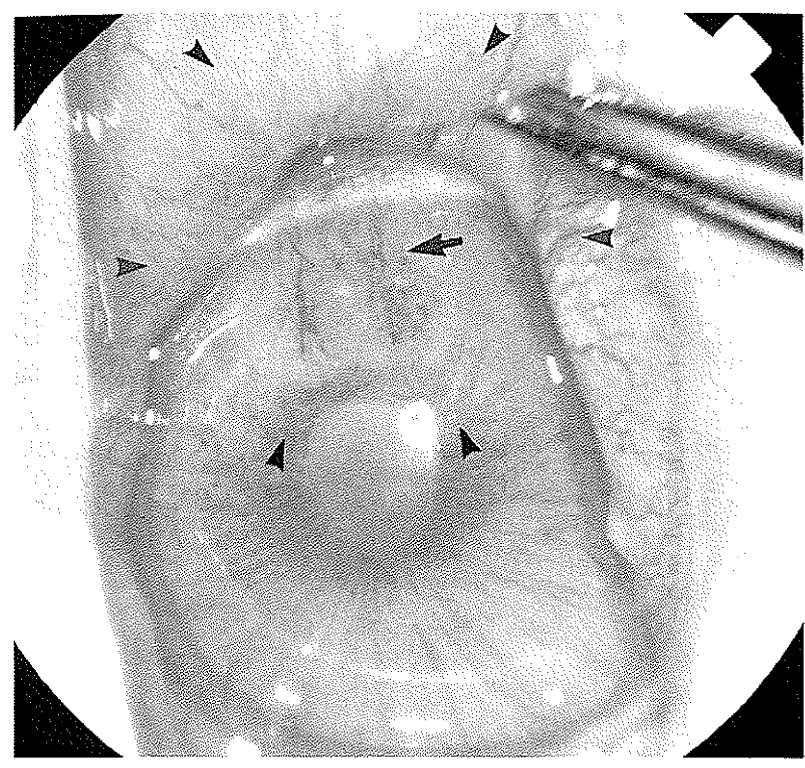

困 7 ポルフィマーナトリウム静注72時間後の中等度照 射例。治療 3 時間後前眼部写真。

矢完で用まれた範用がはばレーザー照射部位であ る。知印の新生血䈏は暗赤色を呈し、治療前より やや太い。照射野内の蛙彩は白色調で，瞳孔縁に は充血がみられる。結膜浮腫がみられる。

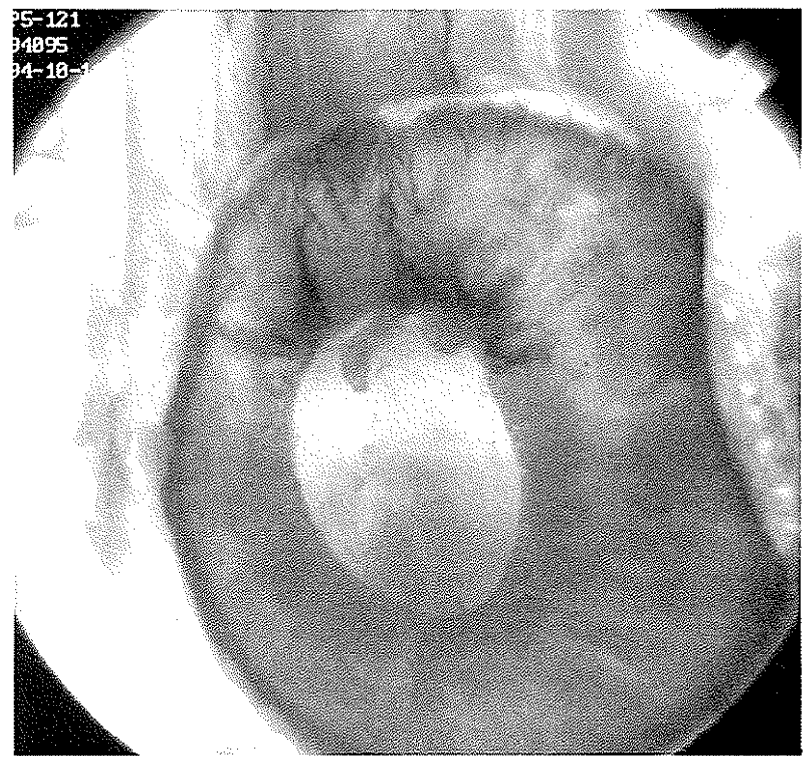

図 8 ポルフィマーナトリウム静注72時間後の中等度照 射例。治療 3 時間後の螢光造影。

（造影開始 1 分 8 秒）

新生咱管は造影されない。照射野の虹彩は瞳孔縁 で低螢光，その他で過螢光を星する。結膜血管の

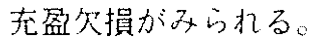

円であっだ，照射野以外の瞳孔縁に立且を諗めた。結 膜浮腫を軽度認めた（図 7)。螢光造影では新生血管は 造影さ机ず，照射野の睡孔縁虹彩血管の立盈欠損上他の 


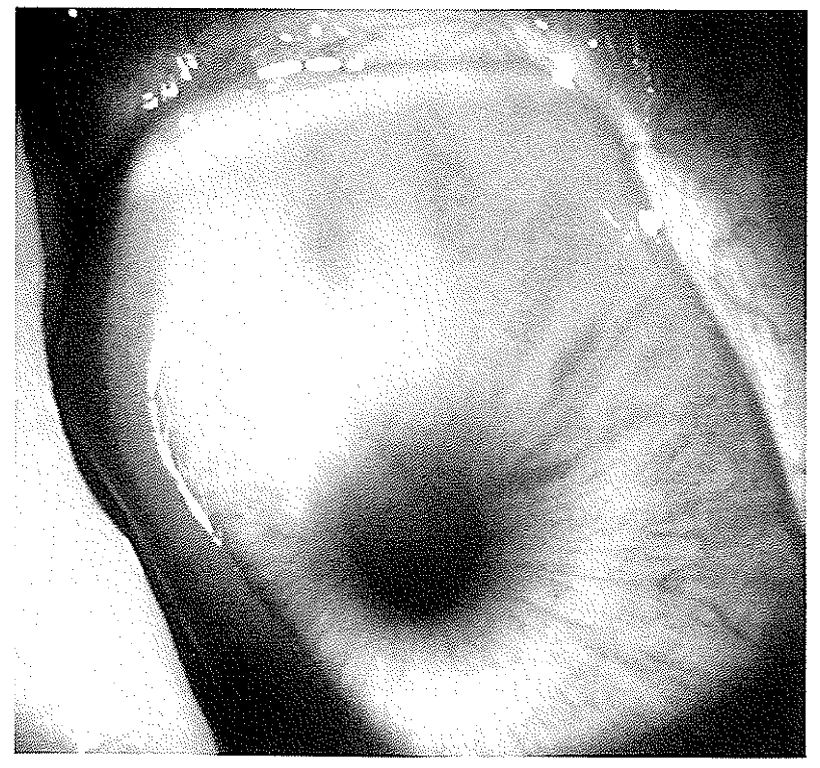

図 9 ポルフィマーナトリゥム静注72時間後の中等度照 射例。治療 3 日後の前眼部写真。

新生血管は暗赤色で，周囲の角膜混濁がみられる。 照射野内の虹彩には線状，斑状出血がみら机る。

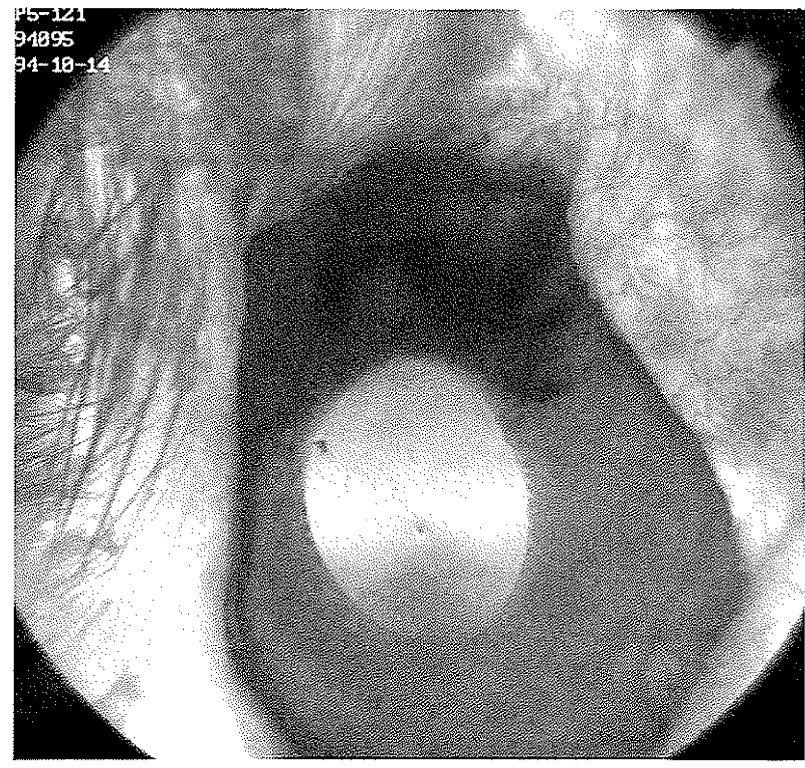

図10 ポルフィマーナトリウム静注72時間後の中等度照 射例。治療 3 日後の螢光造影写真。

(造影開始 1 分16秒)

新生血管は造影さ㧈ない。照射野内の虹彩は低螢 光を呈する。

虹彩血管からの色素漏出が認められた。結膜血管の充盈 欠損もみられた（図８）。3日後には新生血管は暗赤色 で血流がみられず，周囲の角膜混濁がみられた。照射野 の虹彩は白色調を呈し，線状および斑状出血がみられ， 瞳孔はわずかに䋖長の榜円形を呈した。結膜浮腫は軽減 した（図 9)。螢光造影では新生血管は造影されず，照

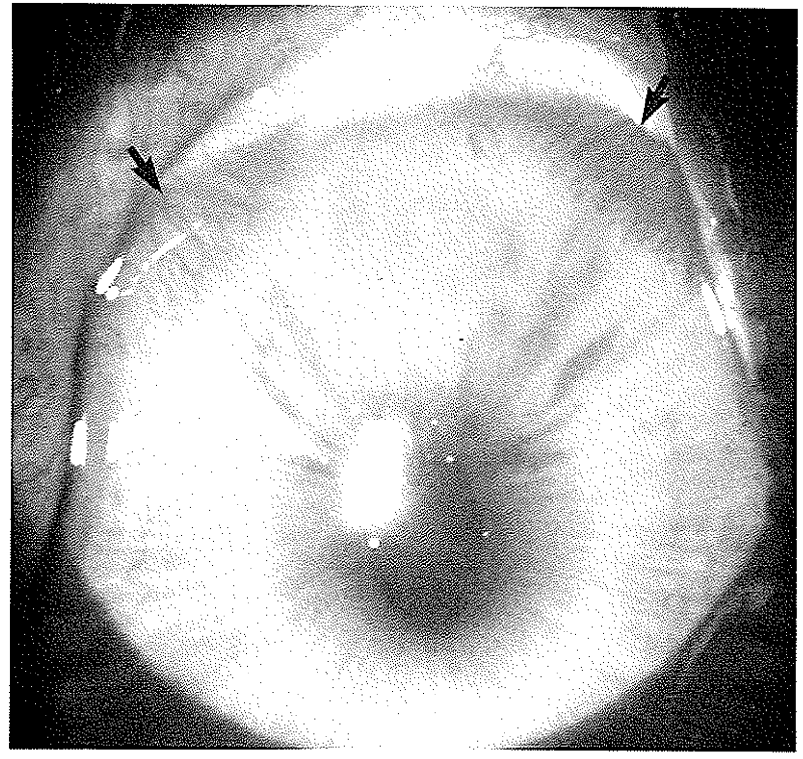

図11 ポルフィマーナトリウム静注72時間後の中等度照 射例。治療 1 週後の前眼部写真。

治療された元の新生血管は消失しているが，治療 䑧にはなかった密な新生㑑管（矢印）が出現して いる。角膜泥濁は3 日後よりやや軽減している。 虹彩出血がみら机る。

射野の虹彩に充盈欠損上出血に上る螢光のブロックがみ られた（図10）。眼底検查では視神経乳頭下方の捘極部 に限局的に脈絡膜血管が疎で脈絡膜出血を伴うところが みられた。1透後には新生血管は不明で，角膜混濁は3 日後からやや軽減がみられた。しかし，治療前にはなか。 た新生血管が照射野辺縁の角膜輪部から角膜中央に向 かって密に伸びていた。照射野の虹彩は白色調を呈し出 血がみられた（図11）。螢光造影では元の新生血管は造 影されなかったが，照射野の虹彩には充盈欠損と出血に よるブロックがみられた。眼底检查では3日後に脈絡膜 出血の存在した部位に脈絡膜大血管の狭小化がみられた。 2 週後には照射野辺縁から伸展した多数の新生血管は消 退傾向を示し、比較的踈な新生血管がみら机た。照射野 の虹彩は白色調を呈したが、油血は消退傾问を示し，瞳 孔は繸長の棛円形であった。螢光造影では再発血管が造 影され、虹彩の充盈欠翼部は小さくなった。眼底所見は 1 週後と同檬であった。

3 ) 強度照射〔ポルフィマーナトリウム静注48時間後 に照射した眼

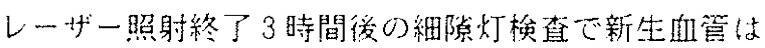
太く暗赤色に变化し，血流の途絶がみら机た。照射野の 虹彩は白色調を呈した。強い結膜浮腫を来したが，角膜 の变化は認めなかった。瞳孔は軽度散大した（図12）。 螢光造影では新生血管は一部を除いて，大半は造影さ机 


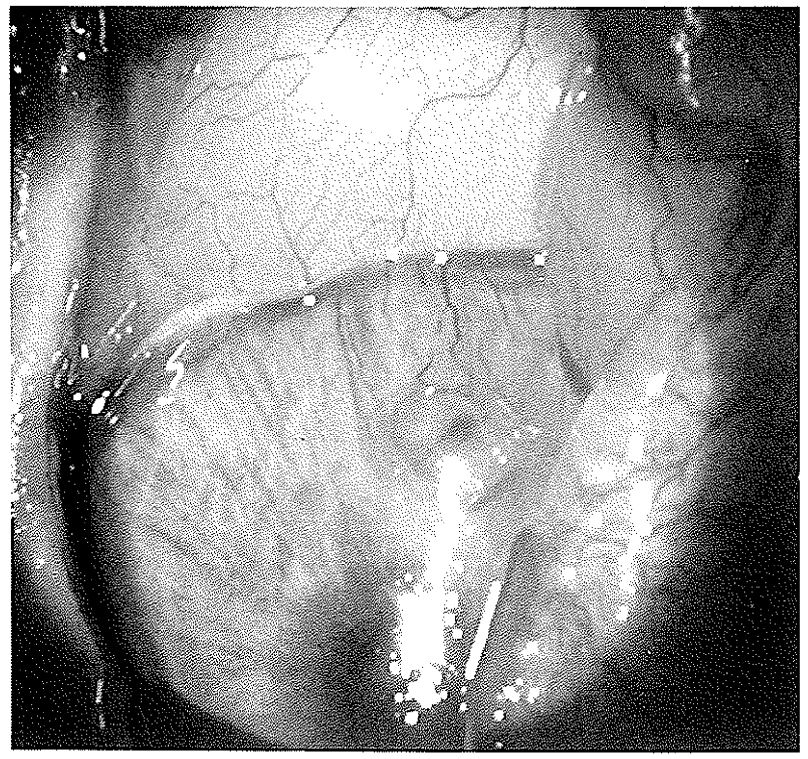

図12 ポルフィマーナトリウム静注48時間後の強度照射 例。治療 3 時間後の前眼部写真。

新生血管は暗赤色で，向流途絶がみられる。結膜 浮腫は高度である。

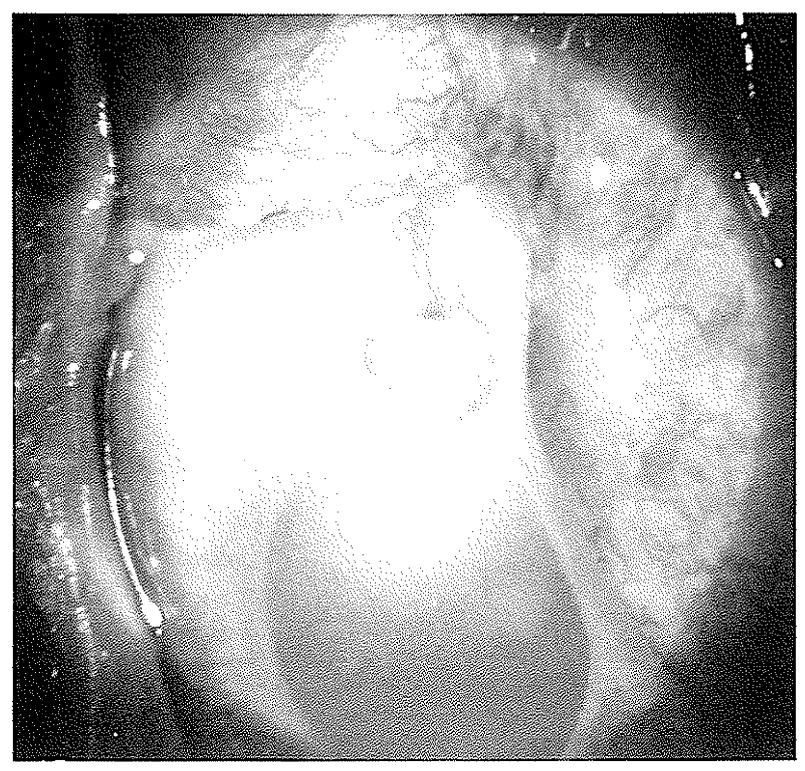

図13 ポルフィマーナトリウム静注48時間後の強度照射 例。治療 3 日後の前眼部写真。

新生血管には血流途絶がみられ，周囲の角膜混濁 は商度である。照射野の虹彩は曰色調で，その周 囲には卉血がみら扟る。睡孔は散大している。結 膜浮腫がみら扎る。

なかった。照射野の虹彩には充盈欠損が生じ，その周[囲 に色素漏出がみられた。照射野内の結膜血管も造影され なかった。3日㣪には新生血管は暗赩で血流は途絶し。 角膜混濁が著名であった。照射野の虹彩は白色調で，非 照射部虹彩の充血が著名であった。結膜浮腫はやや軽減

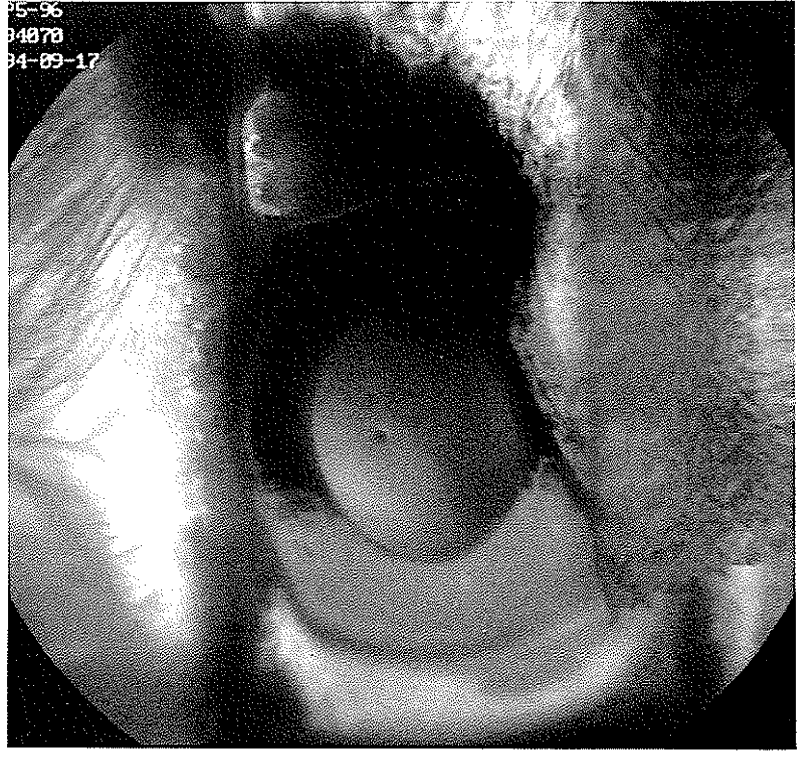

図14 ポルフィマーナトリウム静注48時間後の強度照射 例。治療 3 日後の螢光造影写真。(造影開始17秒) 照射野に相当する筙囲は低螢光を呈する。すなお ち新生血管、虹彩血管、結膜血管は造影されない。

したが，充血がみら机た。瞳孔は散大していた（図13）。 螢光造影では新生血管、照射野内の虹彩血管, 結膜血管 の充盈欠損が諗めら㧈た（図14）。眼底検查では後極部

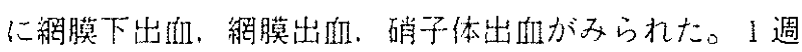
後には元の新生血管は維い筋状となったが，新たな新生 血管が照射野辺緣の角膜輪部から密に增殖した。照射野 虹彩の白色化之，非照射部虹彩の充泣，出血上，前房出 血犬゙みら机た。結膜浮腫は消退したが，充血はみられだ。 瞳孔は散大していた。螢光造影では新生血管，照射野内 の虹彩血管，結膜血笛の充盈欠損が諗められた。照射野 周囲の虹彩血管から色素漏出がみられだ。眼底検査では

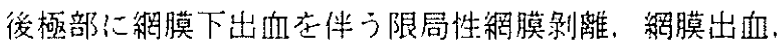
硝子体出血がみられた。2遇後には元の新生血管は不明 瞭だが、そ扎とは翼なる新生血管が多数みられ，角膜は 混漝していた。照射野の虹彩は白色で，抁張，蛇行した 血管がみら扎た。韭照射部の虹彩血管の搪張もみら扎た。 前房内に近腫が存在した（図15）。螢光造影では元の新 生血管は造影されないが，己狆之は異なる新生血管が多 数造影さ扎た。眼底検查では徭極部に約8 致頭径大の脈 絡膜血管の観察されない部位之航膜出们，螕膜前出血が みられた。

\section{2. 組織学的所見}

組織学的所見は治療条件に関わらず。細隙灯㧍上び螢 光造影梚查所見に応じた変化索示した。つまり、レーザー 照射直後と3日㣪に向流のみられなかった標本では，新

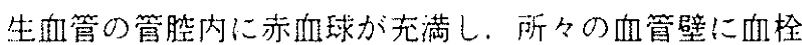




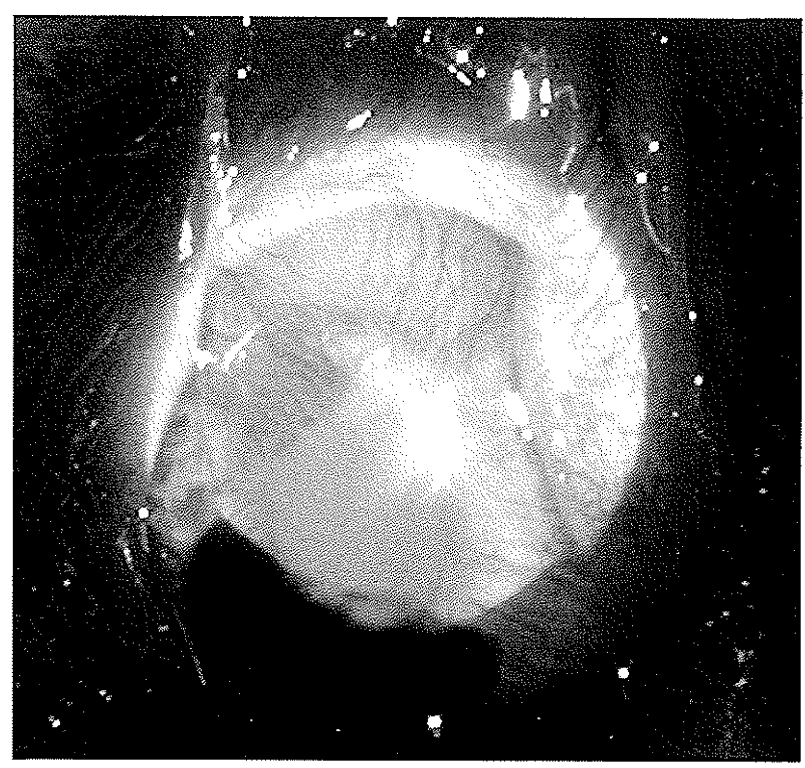

図15 ポルフィマーナトリウム静注48時間後の強度照射 例。治療 2 週後の前眼部写真。

照射野辺縁の輪部から新生血管の伸展がみられる。 虹彩出血之前房内の数血塊方存在する。

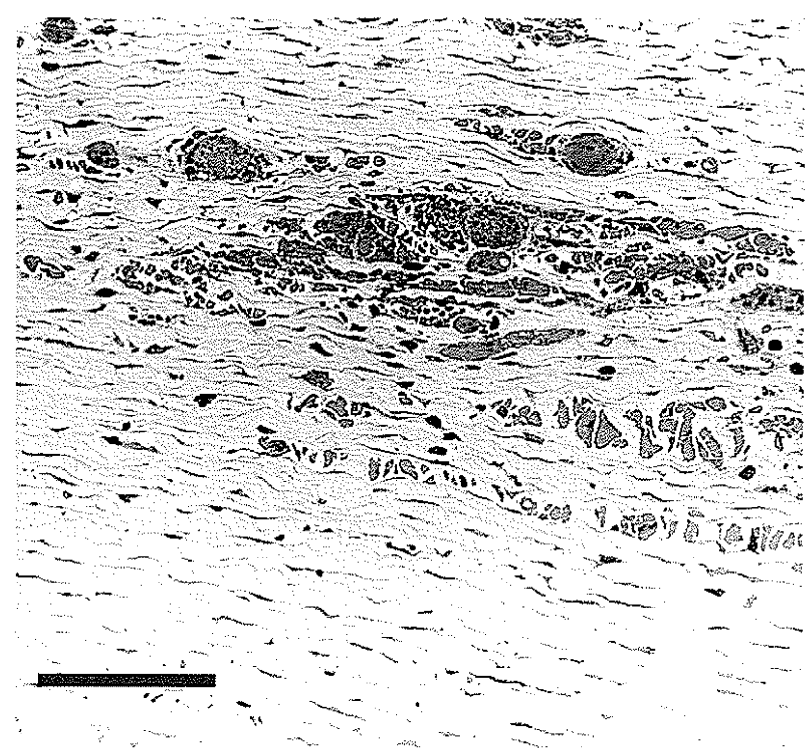

図16 ポルフィマーナトリウム静注24時間後の弱度照射 例。治療 3 時間後の角膜光顕写真。

(トルイジンブルー染色，バー $=100 \mu \mathrm{m}$ )

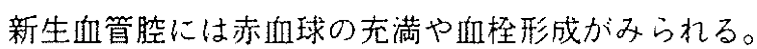

形成がみられた（図16）。また，角膜実留内の出血がみ られた。1 週から 2 週後に新生血管の再疎通や新なな血 管の発生がみられた標本では，管㓐の開存した血管が認 められた。中等度および強度照射では再発した䘏管周囲 に白血球の浸潤がみられた。

虹彩は，螢光造影で充盈欠損のあった標本では管腔内 に血栓㔙成と赤血球の充満した血管がるら机たが，管腔

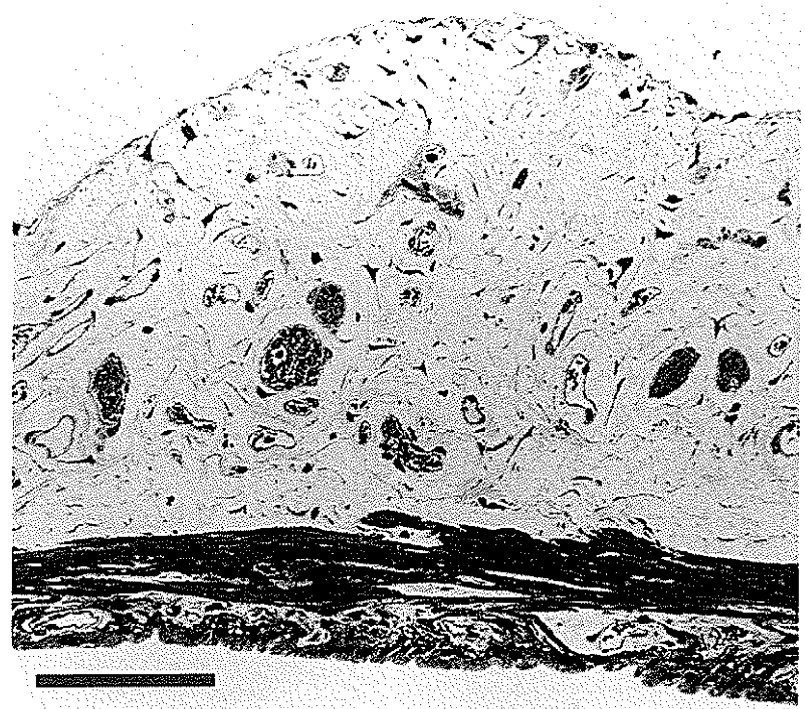

図17 ポルフィマーナトリウム静注48時間後の弱度照射 例。治療 3 時間後の虹彩光顕写真。

(トルイジンブル一染色，バー= $100 \mu \mathrm{m}$ )

管腔の保た机た血管と。血柽と浾血球の夼満で閉 兴した伹管がみら扎る。

の開存した伹管もみら扎た（図17）。芚盈欠損がなく漏 出のみですった標本では血管腔の開存がみられ，衈管壁 の異常はみら机なかった。

以上，各照射強度の典型的所兒在記载したが，表 2 に 今回観察した全ての眼の結果をまとめた。新生欰管の開 塞とは細陪灯，螢光造影検査で血流の途絶が諗めら扟た 場合で，この内光影標本観察も行えたものでは管脉内に 赤血球の充満と血栓形成がみられた。再疎通之は一度閉 塞した新生血管に再度血流が認められた場合で，再発と は元の新生血管とは翼なる向管が生じた場台を意味する。 虹彩の所見はレーザ一照射野内の变化のみを記したもの で，漏出とは螢光造影検查で色素の漏出を認めた場台. 閉塞とは螢光造影検査で立盈欠損を諗め，光顕標本で血 栓形成による管腔閉塞を認めた場台である。虹彩出们， 前房出血は細隐灯で観察されたものである。な拉，表中 の各所見の眼数の台計が観察眼数在超えている簓所は。 それらの所見が同一眼に重複してみら扎たものである。

\section{3. 対照実験の結果}

対照実験ではアルゴン緑レーザー照射眼ならびにポ フィマーナトリウム投与のみの眼では，新生血管に变化 はみられず，角膜、虹彩、眼底の異常も諗めなかった。 また，螢光造影検查では新生血管に色絜の流入在認めた （図18）。組織学的には角膜奏筫内に血管腔存認め，虹彩 衈管の潩常はみられなかった。 
表 2 治療条件別の角膜新生血管開塞および虹彩障害を來した眼数

弱度照射

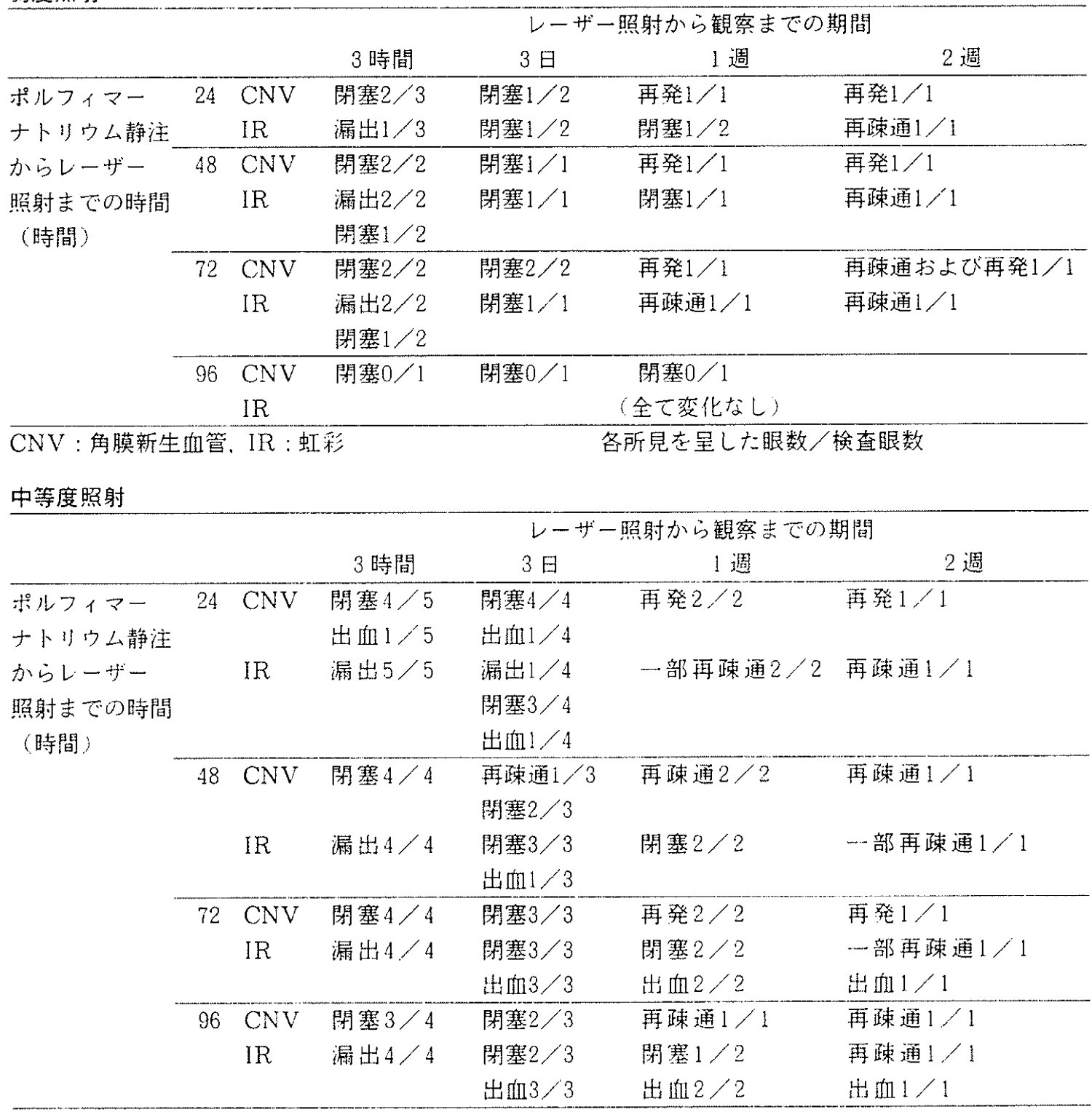

$\overline{\mathrm{CNV}}$ :角膜新生的管。IR:虹彩

各所兒を呈した眼数〉検査眼数

強度照射

レーザー照射から観察までの期間

\begin{tabular}{|c|c|c|c|c|c|c|}
\hline & & & 3 時間 & 3 日 & 1 週 & 2 週 \\
\hline \multirow{13}{*}{$\begin{array}{l}\text { ポルフィマー } \\
\text { ナトリウム静注 } \\
\text { からレーザー } \\
\text { 照射までの時間 } \\
\text { (時間) }\end{array}$} & 24 & CNV & 閉塞 $8 / 8$ & 閉塞6/6 & 再発 $1 / 3$ & 再発1/2 \\
\hline & & IR & 漏出 $1 / 8$ & 閉塞 $6 / 6$ & 閉塞 $3 / 3$ & 閉塞 $2 / 2$ \\
\hline & & & 閉塞 $7 / 8$ & 出任 $6 / 6$ & 出血 3 & 出 ffn $2 / 2$ \\
\hline & & & & 前房出㕷? & & \\
\hline & 48 & $\mathrm{CNV}$ & 闑塞 $6 / 6$ & 閉塞 $4 / 4$ & 再発 $3 / 3$ & 再発2/2 \\
\hline & & IR & 漏出 $1 / 6$ & 閉塞 $4 \leftrightharpoons 4$ & 閉塞 $3 / 3$ & 再柾通 $2 / 2$ \\
\hline & & & 閉塞 $5 / 6$ & 出政2，4 & 出血 $2 / 3$ & \\
\hline & 72 & $\mathrm{CNV}$ & 閉塞 $6 / 6$ & 閉塞 $5 / 5$ & 再発 $2 / 3$ & 再発 $2 / 2$ \\
\hline & & IR & 漏出 $4 / 6$ & 閉塞 $5 / 5$ & 閉塞 $3 / 3$ & 再柾通 $2 / 2$ \\
\hline & & & 閣塞 $2 / 6$ & 出血 $3 / 5$ & 出 nlli $3 / 3$ & \\
\hline & 96 & $\mathrm{CNV}$ & 閉塞 $5 / 5$ & 閉塞 $4 / 4$ & 再発 $3 / 3$ & 悔発 $1 / 1$ \\
\hline & & IR & 漏出 1 < 5 & 閉塞 $4 / 4$ & 閉塞 $3 / 3$ & 漏出 1 / 1 \\
\hline & & & 閉塞 $4 / 5$ & 出伹4 $/ 4$ & 出租 $3 / 3$ & \\
\hline
\end{tabular}

CNV：舫膜新生向管，IR：虹彩

各所胃在呈した眼数ノ検查眼数 


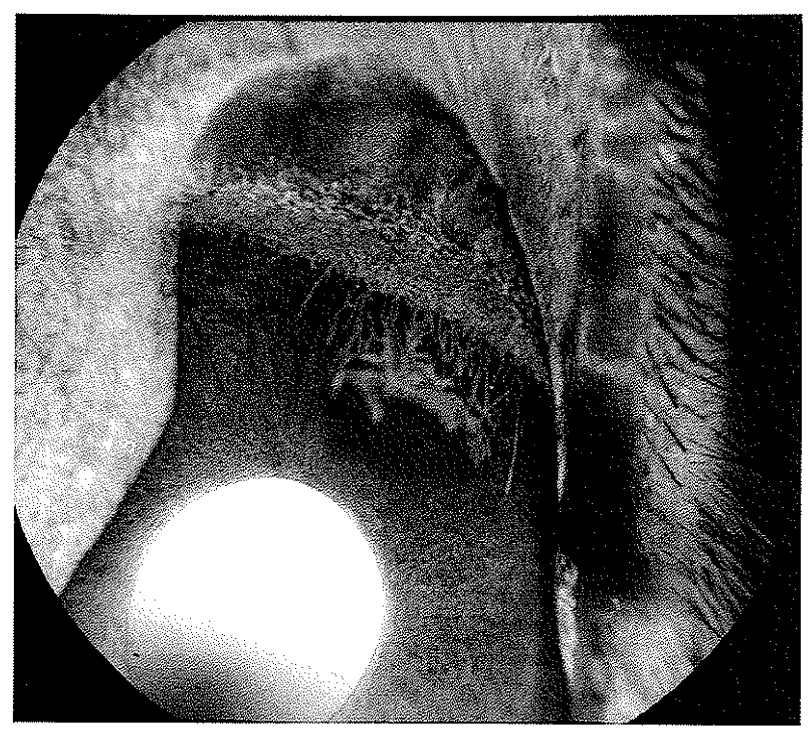

図18アルゴン緑レーザー照射のみを行った対照眼の螢 光造影写真。(造影開始13秒)

新生血管には色素流入が認めら机る。

\section{IV 考 察}

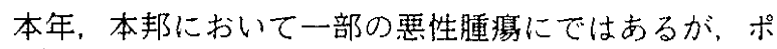
ルフィマーナトリウム(フォトフリン注）の人体投与 が認可された。これにより今後の適応拡大も期待できる ので，我々は本物質を使用した実矣を行った。なお，他 にローズベンガルが人体投与を認められており，眼科領 域での基礎的報告もあるがタ)、はー17).20)，光化学作用 自体が弱いともいわれ，今娞検討を要する。

ポルフィマーナトリウムは400nm前後の近紫外域に 強い吸収帯と500〜600 nmにかけた可視域に吸収帯を持 つ。近紫外光は発痘性や水晶体での吸収 ${ }^{26)}$, 視細胞に 対する障害作用 ${ }^{27}$ が指摘されていることから, 光化学 治療の励起光には適さない上考えられる。悪性腫瑸治療

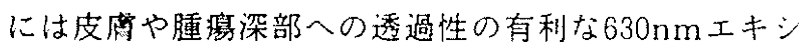
マ色素レーザーが使用されるが2゙)、293，眼球では緑色 光でも十分に透過可能であり，しかも緑色光が吸収スペ クトル上赤色光より吸収がよいこと, 眼科臨休でアルゴ ン緑レーザー $(514 \mathrm{~nm})$ は汎用されており，臨床応用 の際に高価なレーザー装置の購入が不要なことからアル ゴン緑レーザーを励起光とした。

異なる病態において角膜、虹彩、絧膜、脈絡膜など種々 の組織に新生血管が生じ，いずれもが光化学治癔の検討 対照になり得るが，今回は実験的に作成しやすく、観察 も谷䍙な角膜新生血管を実験モデルに使用した。実験的 角膜新生血管作成方法はb-FGF含有ペレット包埋 法 $^{25}$ 以外に，角膜通系法多，インターロイキン 2 包埋

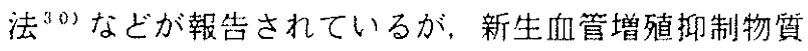

の開発等で十分な唡討がなさ扎ているペレット包埋法を 選んだ。予備的に調べたペレット包埋法の経過では、ぺ レット包埋 1 㥜前後に角膜輪部からペレットに達寸るや や密な新生血管が生じ、その㣪新生血管はやや疎となっ て, 包埋 2 週後以降ははとんど变化なく約 2 か月間存在 し，その徯徐々に消退した。実験には包埋 2 週後の增殖 の安定した時期を新生血管モデルとして使用した。

光化学治療後に細妳灯娭查で新生血管か暗赤舁で血流 がみられず，螢光造影検查でも色素流入がない場台，新 生血管の閉兴とした。光顕標本では管腔壁の血栓付着、 管腔内の赤血球光満がるら扎たししかし，血管壁の詳䄄 な形態学的变化は光顕的観察では限界がある。今回光顕 で観察した標本の一部在透過型電顕で観察したところ， 血管内皮細胞，壁細胞の变性やところに上り内皮細胞の 脱落がみられ，血栓形成の生じている所見が得られてい るが(未発表結果)，今後さらに検討が必要である。

また，照射出力が小さいことと，対照実娩でまったく 変化がなかったことから，今回の治療効果はレーザーの 熱作用ではなく，ポルフィマーナトリウムとアルゴン レーザー相互の光化学反忘によるものと考えた。

ポルフィマーナトリウム静注からレーザー照射までの

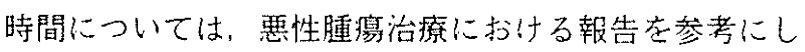
た24)，283．29)。悪性腫獥治療では静注48～72時間後が 最適時期上されるので，今回は24〜96時間後の間の 4 時 点において、いつが新生血管治療に適するるか娭討した。 その結果, 弱度照射ではポルフィマーナトリウム静注 24 〜72時間後に照射を行えば，新生血曾の閉塞が得られ， しかも虹彩など新生血管周国の組織障害も可逆性である ことが解った。中等度照射では24〜72時間後の照射にて

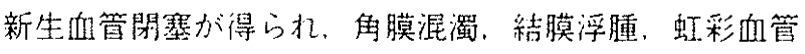
閉塞も一過性であったが，眼底血管への影響之新生血管 の再発が問題であった。眼底の障害は瞳孔おうよびメラニ ン色素をもたない虹彩在透過した照射光に上り，脈絡膜 血管が光化学作用で開塞されたものと推測される。強度 照射では24〜96時間後のいずれの照射でも全例新生血管 は閉塞したが，1邀後に新生血管の激しい再発がみられ。 また，照射野の虹彩血管の閉塞と，その周国血管の向液 眼栅の破綻、虹彩出向、前房出向が生じた。角膜混濁や 眼底の障害も強いことから，新生血管治療には過剩照射 と考えら扎た。

治療 1 週後の新生血管再発の原因としては。まず。ぺ レット内に残存したb・FGFによる影響が誟え的る。 しかし，残存b-FGFによる作用のみが再発原因なら。 照射強度の趡いにより坶発の程度が翼なることが説明で きない。弱度照射での再発はごく軽度だが，中等度，強 
度照射の再発は激しかった。この理由として，照射野の 虹彩血管の胭機能障害に上る前房内炎症の影響が考元ら れる。眼内の炎症により角膜新生血管が生じることは他 にも報告さ扎ている" 。また，虹彩血管，脈絡膜血管 の閉塞に上る血管堌殖促進因子放出の可能性も考えられ る。これらの要因は虹彩, 眼底の障害が強い眼ほど激し い再発を来したことと合致する。その他, ペレット基材 がレーザー照射を受けて変性し，それが刺激性を持った り，基材の変性によりb-FGFが多量に放出されたため に激しい再発が生じた可能性も考えら机る。こ机らの可 能性も照射強度が強いもので再発が激しいことに台致す るので，再発原因についてはさらに検討が必要である。

虹彩や眼底等の新生直管以外の正常組織にも障害が生 じたことは，新生血管の選択的治療という点から問題で ある。理論的にはポルフィマーナトリウムの增殖組織集 積性が高く、新生血管のみに集積するなら，正常組織を 障害することなく新生血管のみを選択的に閉塞できるは ずである。しかし，実際にはいず机の治療条件でも正常 組織の障害を完全に抑えることはできず，ポルフィマー ナトリウムに完全な選択性は期待できない。したがって， 虹彩など周用組織の障害が軽度で可逆的である弱度照射 をポルフィマーナトリウム静注24〜72時間後に行うのが, 実験的角膜新生血管モデルの治療に適しているといえる。 また，正常組織への影響をより小さくする方法として， レーザーの照射方法の改善がある。たとえば今回の上う に角膜に対して重直に照射するのではなく，接線方向に 照射することで虹彩等への照射老さける方法であるが， こ机については今後娭討予定である。ところでこの新 生血管治療に適した照射強度は墨性腫煌治噔に使用され

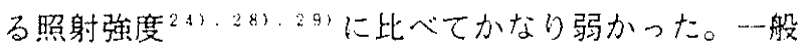

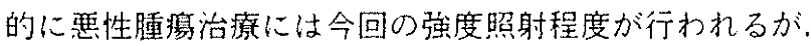
それに比べると角膜新生血管治療には1／8の照射エネ ルギーでよいことになる。これは腫激が厚みを有するた めレーザー光が腫撽媣部まで到達する必瑟があること。 体積が大きいのに対し，新生血管の体積は小さく，しか も透明な角膜内にあることからレーザー光店㵂るものが なく、腫綨より効辛よくレーザー光が作用することが主 な要因上思わ㧈る。

角膜新生血管はそ㧈自体が視力障害を来すのみでなく，

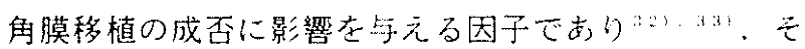
の治療は重要である゙、゙。ポルフィマーナトリウム在 使用した光化学治療は新生欰管のみを選択的に開塞する ことはできないが，照射条件，照射方法の工夫に上り周 四組織の障害老㘯容範囲内に抑えて，角膜新生血管心新 しい治療方法のひとつになり得る上思狆。ささらに眼底
に生じる網膜前，網膜下新生血管などへの応用も期待さ れる。

\section{$\mathrm{V}$ 結 語}

ポルフィマーナトリウムとアルゴン緑レーザーによる 実験的角膜新生血管の光化学治療において，適正な治療 条件老検討した。光化学治療は悪性腫瘦の治療のみなら ず，眼内新生血管の閉塞治療にも有効であることが解っ た。

\section{謝 辞}

徐放性ペレット基材に使用したEVAは武田薬品工業 須藤勝一博士の御好意に上り提供热頂いた。ポルフィ マーナトリウム(フォトフリン注”) は日本レダリ一株 式会社から御提供頂いた。ここに謹んで謝意在表します。

本論文の内容の一部は第59回日本中部眼科学会〈1993 年松江)，第48回日本臨床眼科学全専門別研究会(レー ザ一眼科学，1994年千葉），第99回日本眼科学会総会 (1995年名古屋)に於いて発表した。

\section{文 献}

1) Lipson RL, Bl ades EJ : The photodynamic properties of a particular hematoporphyrin derivative. Arch Dermatol 82 : 508-516, 1960.

2 ) Dougherty TJ. Gindey GB. Fiel R. Boyle DG Photoradiation therapy. II Cure of animal tumors with hematoporphyrin and light. $J$ Natl Cancer Inst 55:115-119. 1075.

3 ) Bugelski PJ. Porter CW. Dougherty TJ : Autor adiograhic distribution of hematoporphyrin derivative in normal and tumor tissue of the mouse. Cancer Res. 41:4604-4612. 1981.

4) Star WM. Marijnissen JPA. Van Den Berg. Block AE. Reinhold HS : Destructive effect of photoradiation on the microcirculation of a rat mamary tumor grouing in 'sandwich' observation chanbers. Progress in Clinical and Bilogical Research. 170. In : Doiren DR. et al (Eds), 637-645 Alan R Liss : New York, 1984.

5) Sel man SH, Kreimer-Birnbaum M, Kl aunig JE. Goldblatt PJ. Keck RW. Britton SL : Blood flow in transplantable bladder tumors treated with hematoporphyrin derivative and light. Cancer Res 44 : 1924-1927. 1984.

6 ) Ber enbaum MC, Hall GW, Hoyes AD : Cere- 
bral photosensitization by haematoporphyrin derivarive. Evidence for an endothelial site of action.

Br J Cancer 53:81-89, 1986.

7 ) Orenstein A, Nelson JS. Liaw L-HL. Kaplan R, Kimel S, Berns MW : Photochemotherapy of hyper vascular dermal lesions: A possible alternative to photothermal therapy? Lasers in Surg and Med 10:334-343, 1990.

8 ) Corrent G, Roussel TJ, Tseng SCG, Watson $\mathrm{BD}$ : Promotion of graft survival by photothrombotic occlusion of corneal neovascularization. Arch Ophthalmol 107 : 1501-1506, 1989.

9 ) Epstein RJ, Hendricks RL, Harris DM : Photodynamic therapy for corneal neovascularization. Cornea $10: 424-432,1991$.

10) Pallikaris IG, Tslimbaris MK : Effectiveness of corneal neovascularization photothrombosis using phthalocyanine and a diode laser $<675$ nm). Lasers in Surg and Med 13: 197-203, 1993.

11) Tsilimbar is MK, Pallikaris IG, Naoumidi II. Vlahonikolis IG, Tsakalof AK, Lydataki SE : Phthalocyanine mediated photodynamic thormbosis of experimental corneal neovascularization : Effect of Phthalocyanine dose and irradiation onset time on vascular occlusion rate. Lasers in Surg and Med 15 : 19-31. 1994.

12) Packer AJ, Tse DT, Gu X-Q. Hayreh SS : Hematoporphirin photoradiation therapy for iris neovascularization. A preliminary report. Arch Ophthalmol 102 : 1193-1197, 1984.

13) Miller JW, Stinson WG, Gregory WA. Elkoumy HA, Puliafito CA : Phthalocyanine photodynamic therapy of experimental iris neovascularization. Ophthalomology $98: 1711-$ 1719, 1991.

14) Royster AJ, Nanda SK, Hatchell DL, Tiedeman JS, Dutton JJ, Hatchell MC : Photochemical inhibition of thrombosis. Fluorescein angiograpic, histologic, and ultrastructual alterations in the choroid, retinal pigment epithelium, and retina. Arch Ophtalmol 106 : 1608-1614, 1988.

15) Wilson CA, Hatchell DL : Photodynamic retinal thrombosis. Rate and duration of vascu- lar occlusion. Invest Ophthalmol Vis Sci 32 : 2357-2365. 1991.

16) Buechi ER, Lam TT. Suvaizidis I, Tso MOM : Injuries induced by diffuse photodynamic action in retina and choroid of albino rats. Morphological study of experimental model. Retina $14: 370-378.1994$.

17) Wilson CA, Saloupis P. Hatchell DL : Treatment of experimental preretinal neovascularization using photodynamic thrombosis. Invest Ophthalmol Vis Sci $32: 2530-2535.1991$.

18) Lin SC. Lin CP. Feld JR, Duker JS. Puliafito CA : The photodynamic occusion of choroidal vessels using benzoporphyrinderivative Curr Eye Res $13: 513-522.1994$.

19) Schmidt-Erfurth U. Hasan T. Gragoudas E, Michaud N, Flotte TJ, Birngruber R : Vascular targating in photodynamic occlusion of subretinal vessels. Ophthalmology 101 : 1953-1961. 1994.

20) Miller H. Miller B : Photodynamic therapy of subretinal neovascularization in the monkey eye. Arch Ophthalmol $111:$ :855-860, 1993.

21) Kliman CHH, Puliafitc CA. Stern D. Borirakchanyavat S. Gregory WA : Phthalocyanine photodynamic therapy : New strategy for closure of choroidal neovascularizationz Lasers in Surg and Med $15: 2-10.1994$.

22) Hayata $Y$. Kato H. Konaka C. Takizawa N : Hematoporphyrin derivative and laser photoradiation in the treatment of lung cancer. Chest 81 : 269-277, 1982.

23) Hayata Y, Kato H. Konaka C: Photoradiation therapy with hematoporphyrin derivative in early and state i lung cancer. Chest 86 : 169177. 1984.

24）加藤治文：光感受性物筫を用いたレーザー光線によ る癌の診断上治療。小黑八七郎：癌治療に抢忛万 レーザー医学，医学㘠書，東京，203-212、1991。

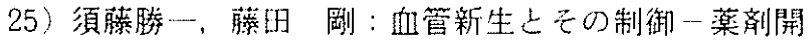
発の立場力ラ一，眼紀40:1431·1443，1989.

26）寺田久雄, 澤 充. 秋葉 純. Norio Ueno. Bireswar Chakrabarti：正常七下水晶体光透過特性. 日眼会 誌98:1101-1108. 1994.

27) Sliney DH : Interaction mechanism of laser 
radiation with ocular tissue. Lasers and Light in Ophthalmol 2:122-128. 1988.

28）小野良祐，池田茂人：肺癌に対する光科学治療。小 黒八七郎：癌治療におけるレーザー医学。医学図書， 東京, 213-228，1991.

29）三村征四郎，一居 誠，奥田 茂：上部消化器癌に 対する光化学治療. 小黒八七郎：癌治療における レーザー医学. 医学图書. 東京、229-238，1991.

30) Epstein RJ, Hendricks RL, Stulting RD : Interleukin-2 induces corneal neovasclarization in $\mathrm{A} / \mathrm{J}$ mice. Cornea $9: 318-323,1990$.

31) Epstein RJ, Stulting RD, Hendricks RL, Harris DM : Corneal neovascularization. Pathogenesis and inhibition. Cornea $6: 250-257,1987$.

32) Maguire MG, Stark WJ, Goltsch, JD, Stulting RD, Sugar A, Fink NE, et al : Risk factors for corneal graft failure and regection in the collaborative corneal transplantation studies. Ophthalmology 101 : 1536-1547, 1994.

33）山上 聡，鈴木康之, 大矢智博, 宮田和典. 水流忠 彦: 全層角膜移植術の拒絶反応発生因子の多变量解 折による検討。日眼会誌98:1097-1100，1994。

34) Baer JC, Foster CS : Corneal laser photocoag. ulation for treatment of neovascularization. Efficacy of $577 \mathrm{~nm}$ yellow dye laser. Ophthalmology $99: 173-179,1992$. 